\title{
Faktor-Faktor yang Mempengaruhi Niat Konsumen Untuk Menerima Iklan Suara di Jakarta
}

\author{
Atok R Aryanto, Bambang Sapto H., Laksmi Savitri, Perry E. Ronaldo, Rio Affianto
}

School of Business and Economics Universitas Prasetiya Mulya

JL. RA. Kartini (TB Simatupang), Cilandak Barat Jakarta Selatan, Jakarta 12430 Indonesia.

*. Corresponding Author : penerbitan@pmbs.ac.id

\begin{abstract}
Based on significant declining revenue in the past years suffered by the prominent telecommunication company in Indonesia, PT XL Axiata, we proposed to compensate the declining revenue by inserting advertisements in free voice call service. The advertisements would be expected to generate some revenue for the company. The declining revenue has been caused by disruptive business in this industry. Prior to that, it would have been necessary to conduct a research to determine what factors affect their intention to listen to voice advertising via voice call service. The result of the survey has supported 5 out of 8 hypotheses developed. Perceived Utility (PU), innovativeness (IN), and attitude toward ads in general (ATA) affected positively the attitude toward mobile ads (ATM). Meanwhile such attitude (ATM) positively affected the respondents' intention to listen to mobile ads in free voice service. At the same time, social norms (SN) affected positively respondents' plan to listen to mobile ads in the free voice call service.
\end{abstract}

\footnotetext{
Abstrak

Dilatar belakangi oleh penurunan revenue pada perusahaan telekomunikasi terkemuka di Indonesia, PT XL Axiata, karena berkembangnya disruptive business, kami mengusulkan untuk membantu meningkatkan pendapatan kembali. Salah satusolusi adalah dengan memperdengarkan iklan pada layanan bertelepon melalui ponsel secara gratis, yang diharapkan akan memberikan pendapatan tambahan. Namun sebelum gagasan itu diimplementasikan, terlebih dahulu dilakukan penelitian mengenai sejumlah faktor yang mempengaruhi sikap dan niat bertingkah-laku konsumen di Jakarta terhadap iklan suara melalui ponsel. Hasil dari penelitian itu menunjang 5 dari 8 hipotesa yang dikembangkan. Persepsi manfaat (PU) dari ponsel, kemauan untuk mencoba hal-hal baru (IN), dan sikap positif terhadap iklan secara umum (ATA) mempengaruhi secara signifikan dan positif sikap responden terhadap iklan suara pada "layanan telepon gratis" (ATM). Sementara sikap yang disebutkan terakhir ini (ATM) dapat membuat responden berencana untuk mendengarkan iklan suara tersebut. Sementara norma-norma sosial (SN) yang dipersepsikan responden menguatkan niatnya untuk mendengarkan iklan suara "layanan telepon gratis".
}

\section{ARTICLE INFO}

Kata kunci: Kepercayaan (belief), sikap, niat bertingkah laku, iklan suara, bertelepon gratis, ponsel. 


\section{PENDAHULUAN}

PT XL Axiata Indonesia telah menghadapi masalah finansial beberapa tahun belakangan ini, dimana penghasil pendapatan utama dari layanan komunikasi telepon dan SMS, mengalami penurunan. Dua sumber penghasil pendapatan ini sudah sejak lama menjadi tulang punggung perusahaan tersebut. Kontribusinya sampai lebih dari $60 \%$ dari keseluruhan pendapatan yang dihasilkan.

\section{Gambar 1. Pola Pendapatan XL Axiata Tbk. dalam Persentase, 2010-2015}

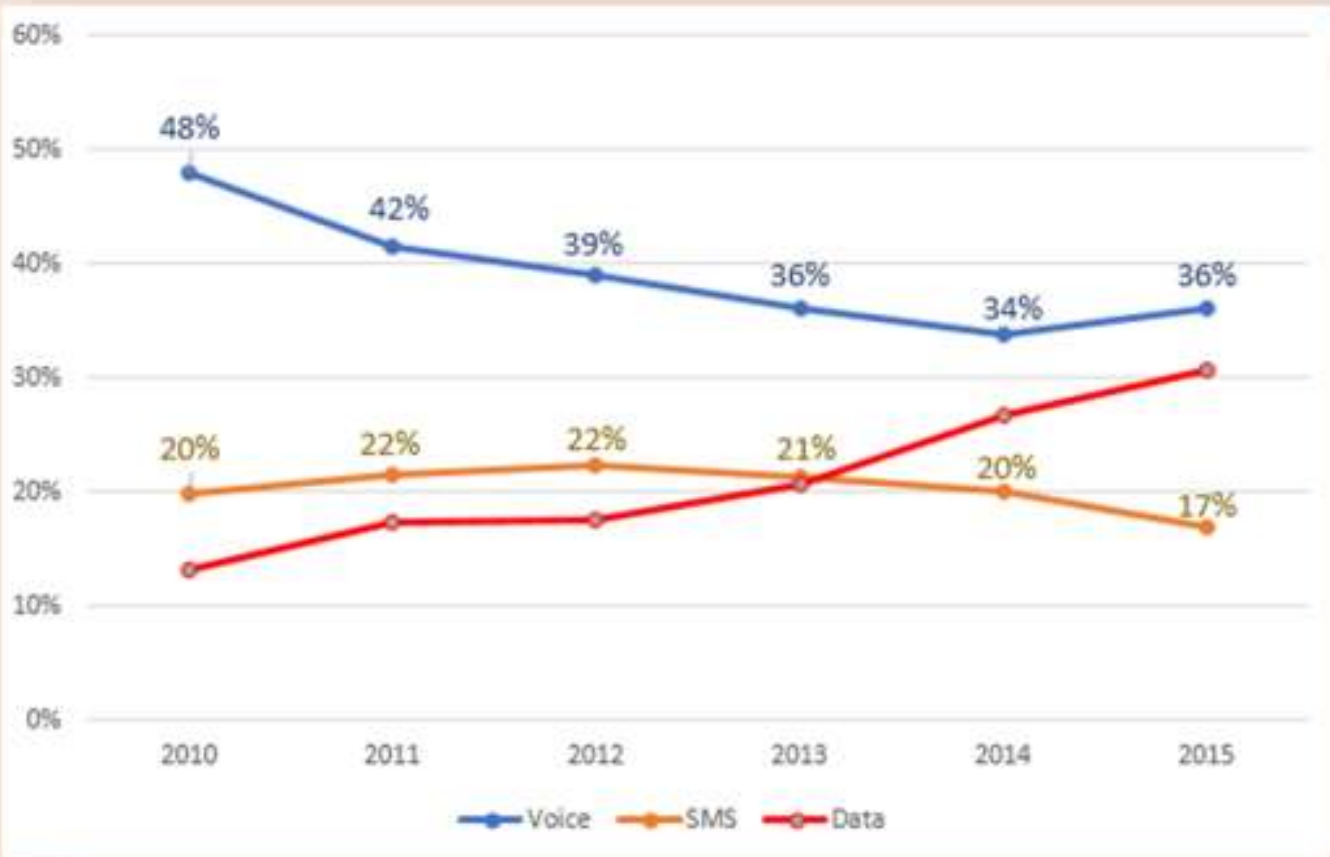

Sumber: Siswarini, Dian (2017)

Hal ini sebagian besar disebabkan oleh berkembang-pesatnya disruptive business dewasa ini pada lahan telekomunikasi dengan menggunakan koneksi internet. Hasil revenue perusahaan tersebut terpangkas secara signifikan oleh karenanya.

Disruptive business sebagaimana digambarkan di atas, seperti contohnya yang sangat populer digunakan di Jabodetabek seperti Facebook messanger, Whatsapp message, Whatsapp data, Blackberry messanger, Line Call, mengambil alih media komunikasi bertelepon menggunakan ponsel. Layanan komunikasi tersebut menggunakan internet 
sebagai jaringannya. Selain mudah diunduh, aplikasi tersebut juga mudah digunakan. Penting pula bagi konsumen, aplikasi itu relatif murah, bahkan ada pula penyedia aplikasi yang tidak mengenakan biaya apapun ${ }^{1}$.

\section{Gambar 2. Operator penyedia layanan data terus berupaya mencapai 'data equilibrium' \&} menumbuhkan pendapatan layanan digital (Siswarini, Dian 2017).

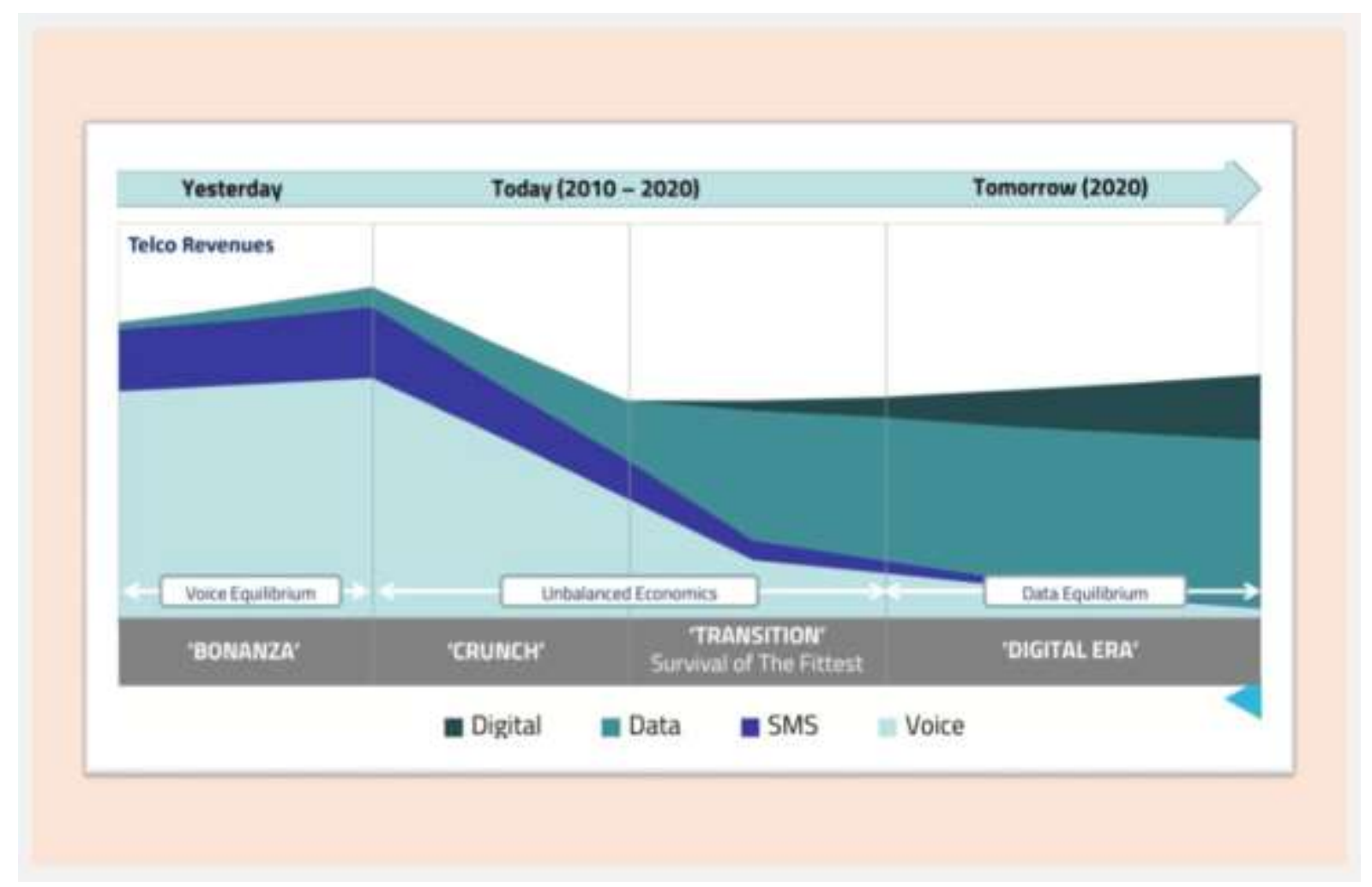

Sumber: Siswarini, Dian (2017)

\section{Usulan Solusi}

Oleh karena 'gangguan' dari berbagai macam layanan data internet di atas, PT XL Axiata secara intensif mulai mencari produk/servis baru untuk mengompensasi pendapatan yang menurun tajam. Banyak gagasan dan aktivitas yang ditelusuri. Kami melihat kesempatan untuk meluncurkan suatu layanan komunikasi, yang diharapkan dapat membantu mengurangi penurunan pendapatan, bahkan membaliknya ke arah pendapatan yang positif. Layanan komunikasi tersebut adalah bertelepon gratis dengan menggunakan jaringan selular

\footnotetext{
${ }^{1}$ BBM, WhatsApp, Line, pada awalnya hanya menawarkan layanan pengiriman pesan teks (messaging), yang mana berkompetisi dengan layanan SMS dari operator seluler. Kemudian berkembang memberikan layanan voice call menggunakan layanan data seperti layaknya seseorang browsing di Internet, dengan demikian layanan ini berkompetisi vis-à-vis dengan layanan komunikasi suara / telepon yang ditawarkan oleh operator seluler.
} 
(ponsel) dimana konsumen mendengarkan iklan terlebih dahulu di dalam bertelepon yang sedang dia lakukan. Jadi konsumen bertelepon gratis selama sekian menit, dimana ia mau mendengarkan iklan sebelumnya selama beberapat detik. Layanan ini kami sebut "Layanan Telepon Gratis”. Pendapatan di dapat diharapkan dari pemasangan iklan oleh perusahaan atau penyedia iklan.

Pemasangan iklan tersebut adalah salah satu bentuk mobile advertising, dimana iklan dipasang melalui media ponsel. Dalam hal ini adalah layanan bertelepon memakai ponsel. Menurut Mansour (2012) dalam jurnalnya, mobile advertising adalah saluran untuk beriklan melalui ponsel dan mempunyai banyak fitur. Sebab itu membuatnya lebih menarik dibandingkan dengan media tradisional dipandang dari kacamata penyedia iklan. Ponsel hampir selalu hanya dipakai oleh pemiliknya. Oleh karenanya pemasangan mobile advertising (melalui ponsel) dapat diukur sampai ke taraf perorangan.

\section{Research Gap \& Pertanyaan Dasar dari Riset}

Telah banyak penelitian dilakukan mengenai mobil advertising tepatnya melalui SMS. Namun belum kami temukan beriklan melalui layanan telepon menggunakan jaringan seluler. Hal ini merupakan Research Gap. Menurut hemat kami sejumlah teori yang dipakai pada bahasan SMS tersebut dapat juga diaplikasikan kepada "Layanan Telepon Gratis" tersebut, oleh karena beriklan pada Layanan tersebut merupakan salah satu bentuk mobile advertising, sebagaimana telah dibahas sebelumnya.

Berdasarkan penalaran di atas, dibawah ini adalah pertanyaan mendasar dari penelitian:

"Faktor-faktor apakah yang mempengaruhi niat konsumen untuk menerima Iklan Suara dalam layanan bertelepon melalui ponsel di JAKARTA?"

\section{TINJAUAN PUSTAKA \& PENGEMBANGAN HIPOTESA}

\section{Tinjauan Pustaka}

Keberhasilan mobile marketing tergantung dari banyak faktor. Ilham H.F Mansour (2012) didalam jurnalnya menyebutkan bahwa untuk menyukseskan mobile marketing, seperti halnya dengan teknologi lain, haruslah mendapatkan izin terlebih dahulu dari konsumen. Oleh sebab itu penelitian mengenai penerimaan (acceptance) konsumen sangat 
penting dalam memberikan masukan untuk keberhasilan diluncurkannya produk/ jasa baru. Tidak hanya pada saat ketika mengimplementasikannya, tetapi juga pada saat keberlangsungan pemakaian selanjutnya.

Lebih jauh beliau menerangkan bahwa niat bertingkah laku (behavior intention) telah dianggap sebagai indikasi dari kesiapan sesorang untuk menampilkan tingkah laku tertentu. Penentu dari seseorang bertingkah laku tertentu adalah niat tingkah laku itu sebelumnya (Peter \& Olson 2010). Niat dipengaruhi oleh sikap konsumen. Sikap didefiniskan sebagai “ $a$ learned predisposition to respond to oneself, other persons, objects, or issues in a consistently favorable or unfavorable way (Cooper \& Schindler 2014 hal.652). Predisposisi yang dipelajari yang menjadi dasar dari respons terhadap seseorang/ sesuatu.

Tsang Et Al (2004) menjelaskan bahwa kebanyakan peneliti menemukan bahwa konsumen umumnya memiliki sikap yang negatif terhadap iklan. Namun pada saat yang bersamaan, tampaknya konsumen bersikap positif terhadap iklan melalui internet. Ini disebabkan oleh pendapat bahwa iklan melalui internet lebih informatif dan menghibur. Di dalam kesimpulannya beliau menjelaskan bahwa:

1) Konsumen biasanya bersikap negatif terhadap iklan, kecuali mereka sudah mengizinkan sebelumnya untuk menerima iklan yang dimaksud;

2) Ada hubungan yang langsung antara sikap dan tingkah laku konsumen.

Lebih jauh Mansour (2012) menerangkan bahwa iklan yang menghibur sangat signifikan mempengaruhi sikap responden, diikuti oleh kredibilitas iklan, dan iklan yang menjengkelkan. Sikap yang positif berkaitan dengan niat untuk menerima iklan pada ponsel. Responden bersedia menerima iklan pada ponsel yang diberikan insentif. Dalam hal kaitannya dengan penelitian kami, insentif yang diberikan untuk konsumen yang mau mendengarkan iklan adalah layanan bertelepon gratis.

Lee (2006) meneliti faktor-faktor yang mempengaruhi tingkah laku konsumen di dalam konteks mobile advertising. Pendekatannya melalui 2 tahapan. Tahap pertama adalah korelasi antara motif seseorang untuk menerima mobile advertising dengan sikapnya terhadap mobile advertising. Tahap ke dua dari penelitiannya membenarkan Theory of Reasoned Action dari Fishbein \& Ajzen. Ditemukan bahwa tindakan positif yaitu berupa menerima mobile advertising sangat dipengaruhi oleh niat yang kuat. Sementara niat yang kuat tersebut dipengaruhi oleh sikap positif, dan sikap positif dipengaruhi oleh motif yang kuat pula. 
Theory of Reasoned Action (TRA) Model dikaji lebih jauh dalam jurnal Mansour (2012). Dijabarkan bahwa niat dibentuk melalui sikap dan nilai-nilai sosial yang pada gilirannya membentuk bahkan menentukan tingkah laku. TRA adalah teori mengenai niat bertingkah laku yang telah banyak diteliti dan diaplikasikan untuk meramalkan dan menjelaskan tingkah laku seseorang.

Berdasarkan sejumlah literatur tersebut, kami membuat replikasi dari penelitian I.H.F Mansour (2012) menjabarkan sejumlah faktor yang mempengaruhi sikap konsumen terhadap iklan pada ponsel (mobile advertising), dalam hal ini kami sesuaikan menjadi iklan suara pada ponsel, dan hubungannya antara sikap dan niat untuk mendengarkan iklan suara, dan tingkah laku sesungguhnya. Sikap, niat, dan tingkah laku adalah 3 variable di dalam TRA yang diperkenalkan oleh Fishbein dan Ajzen pada tahun 1970-an.

Bagan di bawah ini mendemonstrasikan bahwa Theory of Reasoned Action yang menjadi model dasar dari riset ini.

\section{Gambar 3. Model Theory of Reasoned Action}

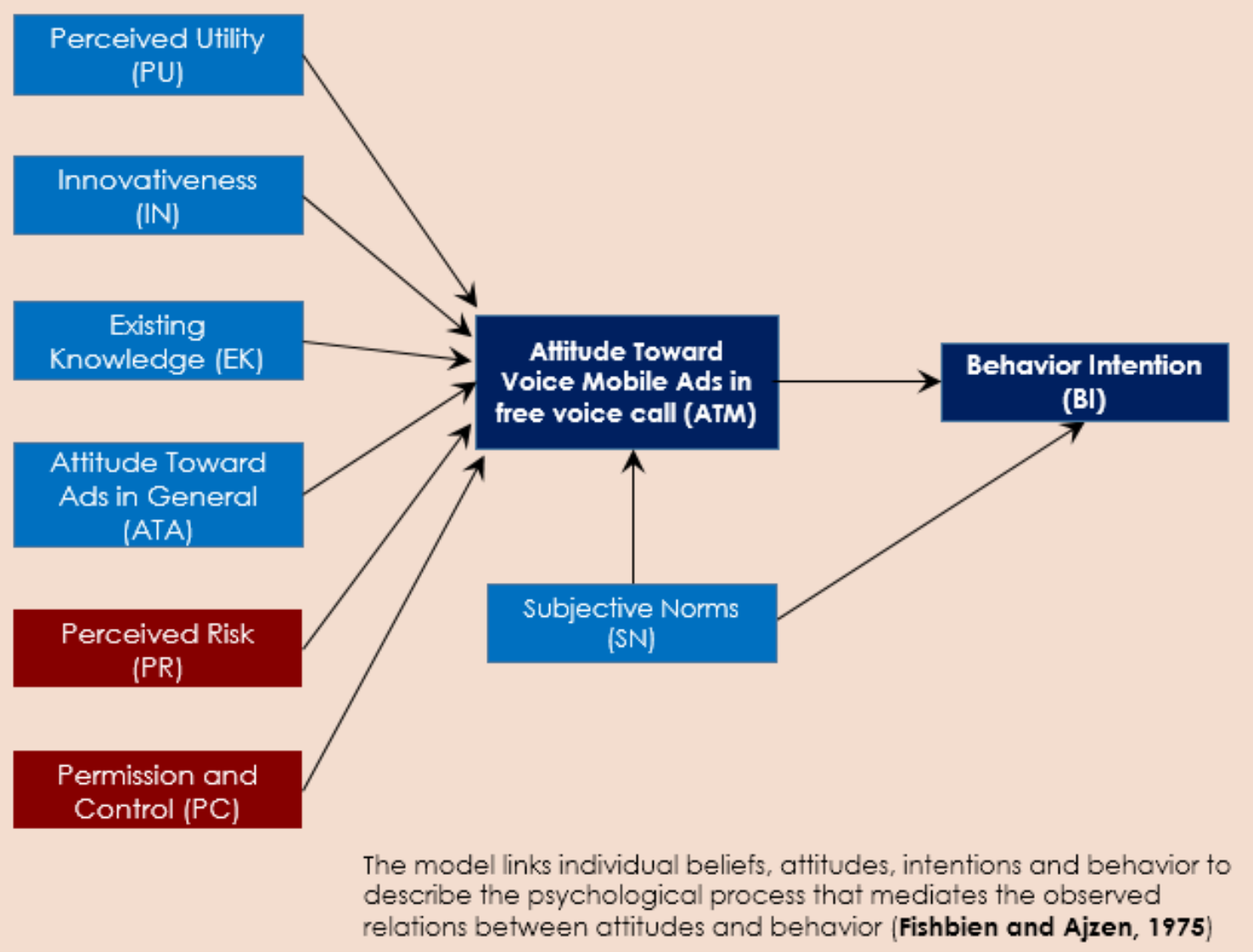


Vol.01, No. 2, 2018

*Model Penelitian berdasarkan Theory of Reasoned Action, sumber dari jurnal "Factors Affecting konsumens' Intentions to accept mobile Advertising in Sudan" (Mansour 2012).

Menurut Mansour (2012), faktor-faktor penentu/ dimensi yang mempengaruhi sikap konsumen, yang diusulkan dalam penelitian ini adalah:

- Personal Innovativeness (IN): adalah derajat keinginan-tahuan seseorang akan hal-hal baru

- Existing Knowledge (EK): adalah pengetahuan yang dimiliki seputar ponsel, misal mengenai teknologinya, features \& benefits, cara penggunaan, dsb.

- Perceived Utility (PU): adalah persepsi manfaat yang dirasakan oleh pengguna, yang dapat memudahkannya dalam mengerjakan perkerjaannya.

- Attitude toward Advertising (ATA): adalah sikap terhadap iklan secara umum.

- Perceived Risk (PR): adalah persepsi mengenai resiko, dalam hal ini penyalah-gunaan data dan hak-hak pribadi.

- Permission \& Control (PC): permission dimaksudkan sebagai izin yang diberikan oleh pengguna ponsel kepada perusahaan telekomunikasi untuk memperdengarkan iklan suara. Control dalam hal ini adalah kekuasaan ada pada pengguna untuk mendengarkan iklan atau tidak.

- Attitude toward Mobile Advertising/Voice Ads (ATM): adalah sikap terhadap iklan suara pada "layanan bertelepon gratis"

- Subjective Norms (SN): norma-norma sosial yang dipersepsikan pengguna ponsel dimana menurut persepsinya dianut oleh orang-orang penting di sekitarnya.

- Behavior Intentions (BI): adalah niat bertingkah laku atau rencana melakukan sesuatu.

\section{IV.2 Pengembangan Hipotesa}

Berdasarkan sejumlah argumen di atas, selanjutnya kami susun 8 (delapan) buah hipotesa terkait dengan niat bertingkah laku terhadap iklan suara yang diperdengarkan melalui ponsel, atau dalam hal ini "Layanan Telepon Gratis".

\section{Hipotesa 1:}


Vol.01, No. 2, 2018

Personal Innovativeness (IN) mempengaruhi sikap secara positif terhadap iklan suara pada "Layanan Telepon Gratis".

Personal Innovativeness menurut Mansour (2012) didefinisikan sebagai keinginan individu untuk mencoba teknologi baru. Seseorang yang inovatif digambarkan sebagai dinamis, komunikatif, keingin-tahuan yang tinggi, petualang, dan mencari tantangan baru.

\section{Hipotesa 2:}

Existing Knowledge (EK) mengenai ponsel mempengaruhi sikap secara positif terhadap iklan suara pada "Layanan Telepon Gratis".

$E K$ dari konsumen memudahkannya dalam mengerti karakteristik dan keuntungan dari suatu inovasi produk. Jadi $E K$ mempengaruhi persepsi konsumen mengenai tingkat kerumitan inovasi (Mansour 2012). Semakin canggih konsumen dalam menggunakan ponsel, secara umum dia akan mempersepsikan semakin mudah untuk mengerti iklan dalam ponsel.

\section{$>$ Hipotesa 3:}

Attitude toward Advertising (ATA) atau Sikap terhadap iklan pada umumnya mempengaruhi secara positif sikap terhadap iklan suara pada "Layanan Telepon Gratis”.

Mansour (2012) membuat hipotesa ini berdasarkan teori dari beberapa literatur kemudian menyimpulkannya. Bila diadopsi dan diaplikasikan untuk tema dibahas di dalam jurnal ini sbb: sikap seseorang terhadap iklan pada umumnya mempengaruhi sikap terhadap iklan pada ponsel, dalam hal ini iklan suara di dalam "Layanan Telepon Gratis". Namun sikap terhadap iklan pada umumnya tampaknya lebih stabil tidak mudah berubah, karena seringnya dihadapkan pada iklan dalam kesehariannya. Sementara suara iklan dalam "Layanan Telepon gratis" baru di cobakan terhadap sejumlah kecil responden, sehingga sikapnya belum stabil dan mudah berubah.

\section{Hipotesa 4:}

Perceived Utility (PU) dari iklan suara pada ponsel secara umum mempengaruhi secara positif sikap terhadap iklan suara suara pada "Layanan Telepon Gratis".

Perceived Utility adalah persepsi manfaat dimana seseorang percaya bahwa pemakaian sistem tertentu akan membantu kinerjanya. Artinya adalah persepsi manfaat 
yang positif terhadap iklan suara pada ponsel, akan mempengaruhi sikap terhadap iklan suara tersebut (Mansour, 2012).

\section{$>$ Hipotesa 5:}

Perceived Risk (PR) dari iklan suara pada ponsel mempengaruhi secara negatif sikap terhadap iklan suara suara pada "Layanan Telepon Gratis".

Persepsi resiko yang dihubungkan pada iklan suara pada ponsel terutama adalah keamanan data pelanggan. Biasanya pelanggan ingin penjagaan terhadap manipulasi data, atau pemalsuan akses data. Selain itu juga terhadap 'privacy' atau kerahasiaan data (Mansour, 2014).

\section{$>$ Hipotesa 6:}

Permission \& Control $(P \& C)$ dari iklan suara pada ponsel mempengaruhi sikap secara negatif terhadap iklan suara pada "Layanan Telepon Gratis"

Mansour (2012) menyimpulkan dari beberapa teori di dalam artikelnya bahwa konsumen biasanya mempunyai sikap yang negatif terhadap iklan suara pada ponsel kecuali mereka memberikan izinnya untuk diperdengarkan iklan suara tersebut. Sebelum konsumen mendengarkan iklan suara itu, biasanya mereka ingin tahu bagaimana dan untuk apa perusahaan iklan mendapatkan data pribadi mereka. Jadi mereka bisa lebih bersedia mendengarkan iklan jika mereka sudah mengizinkan terlebih dahulu. Disamping itu, konsumen berkeinginan untuk memegang kontrol untuk mendengarkan iklan atau tidak.

\section{Hipotesa 7:}

Subjective Norms (SN) mengenai diperdengarkannya iklan suara pada "Layanan Telepon Gratis” mempengaruhi secara positif niat untuk tingkah laku mendengarkan iklan suara tersebut.

Fishbein \& Ajzen (1975) mendefiniskan Subjective Norms sebagai persepsi seseorang terhadap pemikiran orang-orang yang dekat dengannya, apakah dia perlu atau tidak menampilkan tingkah laku tertentu. Mansour (2012) menyimpulkan bahwa SN diperhitungkan sebagai hal yang mempengaruhi seseorang bertingkah laku tertentu. Jadi menampilkan tingkah laku tertentu juga dipengaruhi oleh pendapat orang lain mengenai tingkah laku tersebut.

\section{Hipotesa 8:}


Sikap terhadap iklan suara pada "Layanan Telepon Gratis" mempengaruhi secara positif terhadap niat konsumen untuk bertingkah laku mendengarkan iklan suara tsb (Niat bertingkah laku dikatakan juga sebagai BI atau Behavior Intention).

Sikap didefinisikan oleh Peter \& Olson (2014) sebagai evaluasi seseorang terhadap suatu konsep. Evaluasi adalah respons seseorang yang mengandung afeksi (perasaan, emosi, mood). Jadi evaluasi terhadap suatu obyek bisa menimbulkan perasaan suka atau tidak suka, positif atau negatif. Selanjutnya Mansour (2012) menyimpulkan bahwa Theory of Reasoned Action menerangkan sikap terhadap tingkah laku dan norma-norma seseorang $(\mathrm{SN})$ akan menentukan niat untuk bertingkah laku.

\section{METODOLOGI PENELITIAN}

\section{V.1 Kuesioner}

Metode yang digunakan adalah metode kuantitatif dengan menggunakan kuesioner yang disebarkan di Jabodetabek, dan menggunakan media internet. Kuesioner adalah alat pengambilan data yang paling sering digunakan dalam penelitian bisnis. Digunakannya kuesioner di dalam penelitian ini karena ingin mengukur sikap dan niat bertingkah laku (Cooper \& Schindler 2014).

Lebih jauh Cooper \& Schindler menjelaskan (2014) bahwa pertanyaan-pertanyaan di dalam kuesioner untuk penelitian mengenai sikap dapat menggunakan skala interval. Pertanyaan disusun mulai dari yang umum sampai spesifik kepada hal yang kita tuju. Tujuannya adalah untuk mempelajari kerangka berpikir responsden dan kemudian menyaring informasi-informasi yang diinginkan dengan cara menggiring responden kepada pertanyaan yang lebih spesifik. Kemudian di dalam setiap pertanyaan, memakai skala Likert,yang menunjukkan setuju/tidak setuju terhadap hal yang disukai/tidak disukai. Kekuatan sikapnya tercermin dari skor misalkan angka 1 untuk sangat tidak setuju dan 5 untuk sangat setuju.

\section{V.2 Sampel Penelitian}

Jumlah sampel direncanakan minimum 200, pengambilan secara acak menggunakan media internet karena pertimbangan waktu, biaya dan kepraktisan. Kami melakukan convenience samples, dimana sampel bebas dipilih oleh peneliti termasuk perkumpulan 
teman-teman pada suatu kelompok pada media sosial. Menurut Cooper \& Schlinder (2014), pengambilan sampel semacam ini termasuk ke dalam Nonprobability Sampling, dimana cukup dapat memenuhi obyektif penelitian. Ketika bekerja di lapangan, kami mendapatkan 207 suara yang masuk, dimana 3 (tiga) responden tidak disertakan kedalam analisa karena mengandung data yang tidak valid. Dengan demikian, ada 204 responden yang digunakan.

\section{V.3 Alat Penguji Hipotesa}

Sesuai penelitian Mansour (2012) yang menjadi acuan penelitian ini, digunakan linear regression dalam SPSS (Statistical Package for Social Sciences) untuk menguji hipotesa. Dalam Onlineestatbook.com (2017) disebutkan bahwa Linear regression dipakai karena ingin mengetahui hubungan antara Y (variabel dependent) dan X (variabel independent). Dalam penelitian ini variabel $\mathrm{Y}$ adalah sikap terhadap iklan suara dan niat tingkah-laku untuk mendengarkan iklan suara. Sementara variabel $\mathrm{X}$ adalah faktor-faktor penentu yang disebutkan di halaman 9 jurnal ini. SPSS adalah program komputer yang dipakai untuk analisis statistika (Wikipedia Indonesia, 2016). Delapan buah hipotesa dikembangkan dan hasilnya akan diringkas di dalam bagan pada Bab VI Analisa Data berikut ini.

\section{ANALISA DATA \& HASIL}

Untuk menyelidiki niat bertingkah-laku (behavior intention) dari para konsumen atas mobile advertising berbasis iklan suara ini, kami melakukan survei di ibu kota Indonesia, yaitu Jakarta. Sebanyak 207 responden ikut mengambil bagian dari survei ini, dimana 3 (tiga) di antaranya menjawab secara parsial sehingga tidak kami masukkan ke dalam populasi yang dianalisa. Dengan demikian 204 responden atau 98,55\% dari populasi yang disurvei lolos untuk analisa berikutya.

Ada pun demografi dari para responden adalah sbb: 


\section{Gambar 4. Demografi dari Responden Survei N=204}

\begin{tabular}{|ccc|}
\hline Jenis Kelamin & & $\%$ \\
Pria & 120 & $59 \%$ \\
Wanita & 84 & $41 \%$ \\
Usia & & \\
$>46$ & 33 & $16 \%$ \\
$18-25$ & 29 & $14 \%$ \\
$26-35$ & 73 & $36 \%$ \\
$36-45$ & 69 & $34 \%$ \\
Pekerjaan & & \\
Karyawan & 132 & $65 \%$ \\
Lainnya & 25 & $12 \%$ \\
Pelajar/mahasiswi & 13 & $6 \%$ \\
Wiraswasta & 34 & $17 \%$ \\
Pendidikan & & \\
\hline D3 & 21 & $10 \%$ \\
Lainnya & 21 & $10 \%$ \\
S1 & 125 & $61 \%$ \\
S2 & 37 & $18 \%$ \\
Status & & \\
perkawinan & & \\
\hline Lajang & 74 & $36 \%$ \\
Menikah & 130 & $64 \%$ \\
\hline
\end{tabular}

Data demografi menunjukkan bahwa jenis kelamin terbagi hampir sama rata (59\% pria,41\% wanita), sebagian besar responden berusia antara 26-45 (70\%), 65\% adalah karyawan dan berpendidikan sebagian besar S1, dan sudah menikah. Hal ini dapat menjadi masukan untuk menentukan target pasar.

Dari hasil pengolahan data respon yang didapat, dapat dibuat diagram regresi atas faktorfaktor yang telah dijelaskan dalam Bab IV, sbb: 


\section{Gambar 5 Hasil dari Pengujian Model}

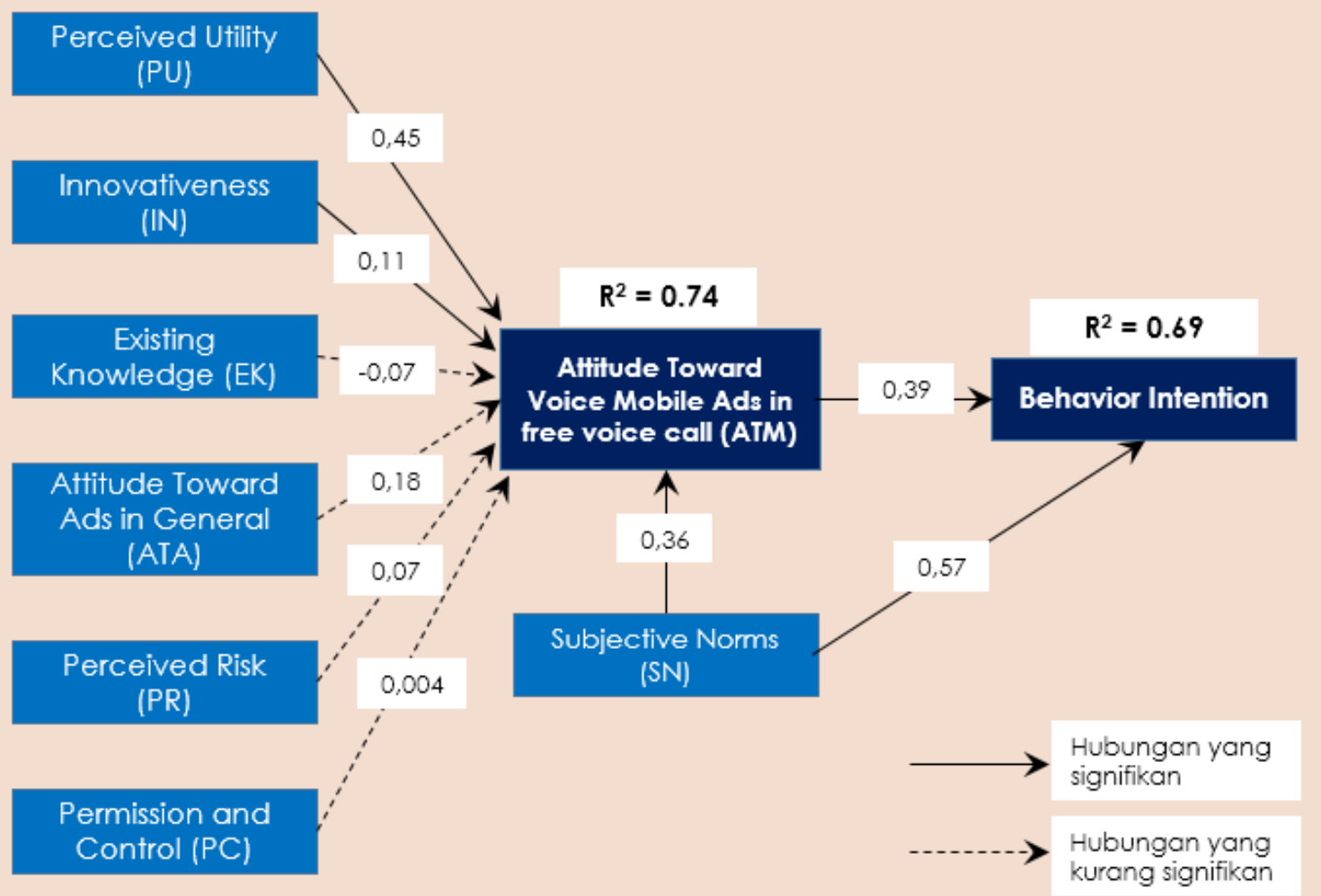

Dari hasil regresi linear terlihat bahwa 5 (lima) hipotesa memiliki hubungan yang signifikan, yang dapat dijabarkan di bawah ini:

- Hipotesa 1 - IN $(0,11)$ menggambarkan konsumen yang senang mencoba hal-hal baru, bersedia untuk mencoba layanan iklan suara. Dengan demikian, inovasi produk yang hendak diluncurkan ini, diharapkan akan mudah untuk diterima konsumen, karena memenuhi kriteria tersebut. Bagi penyedia iklan, hal ini membuka peluang bagi mereka untuk membuat iklan yang kreatif.

- Hipotesa 3 - ATA $(0,18)$ menunjukkan bahwa sikap positif konsumen terhadap iklan secara umum, juga mendukung sikap positifnya atas iklan suara. Dengan demikian bila produk diluncurkan maka resistensi terhadap produk akan rendah.

- Hipotesa 4 - PU $(0,45)$, dapat dipahami bahwa bila sesuatu memiliki nilai yang berguna, maka hal tersebut dapat diterima oleh konsumen; bila iklan suara dipersepsikan positif memberikan manfaat, maka makin menguatkan persepsi manfaat dari layanan telepon gratis dari ponselnya 
- Hipotesa 7 - SN $(0,36)$ menunjukkan bahwa bila sebuah layanan dipersepsikan diterima dalam norma-norma sosial di lingkungan sosial responden, maka hal tersebut dapat diterima oleh konsumen. Norma-norma disini adalah subyektif menurut konsumen. Sehingga diperlukan penggalian lebih dalam dari norma-norma tersebut agar menyesuaikan dengan iklan yang akan dibuat.

- Hipotesa 8 - BI menggambarkan bahwa konsumen yang bersikap positif terhadap iklan berbasis suara ini mempengaruhi secara positif niat bertingkah-laku mendengarkan iklan pada "Layanan Telepon Gratis". Iklan suara diharapkan akan membantu konsumen untuk merencanakan pembelian produk yang dimaksud.

Sedangkan ketiga hipotesa yang lain (H2, H5, dan H6) tidak memiliki hubungan yang signifikan dengan ATM (sikap terhadap iklan suara). Adalah menarik untuk diperhatikan bahwa Hipotesa 5 - Perceived Risk/PR $(0,07)$ dan Hipotesa 6 - Permission\&Control/PC $(0,04)$ tidak menjadi pertimbangan atau pun kekhawatiran dari para konsumen ini. Mungkin saja karena diberikannya insentif yaitu layanan telepon gratis lebih menarik perhatian responden daripada faktor-faktor yang terbukti tidak signifikan tersebut.

\section{KESIMPULAN dan IMPLIKASI}

\section{Kesimpulan:}

Hasil dari penelitian ini menyimpulkan bahwa:

1. Faktor-faktor yang mempengaruhi niat bertingkah-laku mendengarkan iklan suara pada "Layanan Telepon Gratis" adalah persepsi manfaat dari iklan suara tersebut, kemauan untuk mencoba ha-hal yang baru, serta sikap positif terhadap iklan pada umumnya, mempengaruhi secara positif dan signifikan terhadap sikap untuk mendengarkan iklan suara pada "layanan telepon gratis".

2. Faktor-faktor pengetahuan yang dimiliki saat ini, persepsi resiko, serta izin untuk memperdengarkan iklan suara, tidak berpengaruh secara signifikan di dalam penelitian ini.

3. Sikap positif terhadap iklan suara tersebut serta nilai-nilai sosial yang dipersepsikan responden terhadap lingkungan sosialnya mempengaruhi secara positif dan signifikan terhadap niat bertingkah laku untuk mendengarkan iklan suara tersebut. 
Vol.01, No. 2, 2018

\section{Implikasi atas teori:}

Hasil riset kami ini memberikan bukti keabsahan Theory of Reasoned Action (TRA) di dalam penelitian atas mobile advertising, khususnya untuk iklan berbasis suara, dan dapat memberikan sumbangsih bagi literatur atas sikap konsumen dan niat mereka atas mobile advertising dalam beberapa aspek. Pertama, bahwa faktor persepsi manfaat bagi konsumen, faktor kemauan mencoba hal-hal baru, serta sikap positif terhadap iklan pada umumnya adalah sangat penting sebagai faktor untuk menentukan sikap konsumen atas iklan berbasis suara via ponsel. Apalagi apabila diberikan insentif terhadapnya, membuat konsumen semakin tertarik untuk mendengarkan iklan suara ini. Kedua, riset ini menunjukkan bahwa persepsi nilai-nilai sosial memegang peranan penting baik bagi sikap mau pun niat untuk mendengarkan sebuah mobile advertising, dalam hal ini iklan suara via ponsel. Perhatikan Hipotesa 7 - SN memiliki nilai 0,36 kepada ATA dan 0,57 kepada BI di bawah ini:

\section{Gambar 6. Nilai Variansi Hipotesa 7 \& 8}

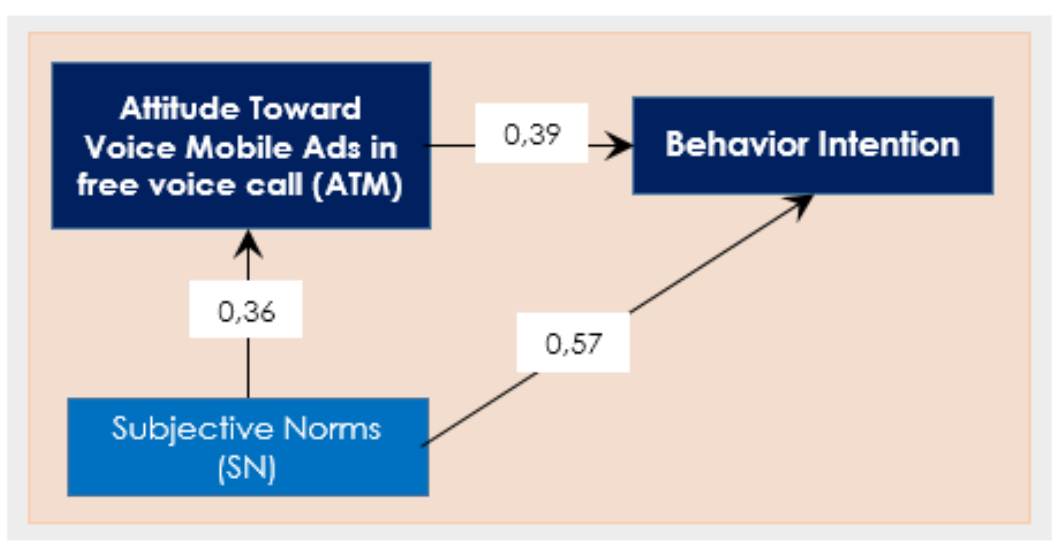

\section{Implikasi atas Bisnis:}

Riset ini menunjukkan bahwa operator seluler yang hendak memberikan layanan iklan suara via ponsel patut untuk memperhatikan aspek manfaat yang diterima oleh pasar potensialnya. Pasar potensial yang didapat dari penelitian ini adalah mereka yang besar kemauannya untuk mencoba hal-hal baru, misalnya teknologi baru, penemuan baru dan tentunya manfaat baru. Perusahaan harus kreatif dalam mencari iklan-iklan yang menampilkan manfaat baik dari sisi ekonomi dan non-ekonomi bagi iklan-iklan yang hendak 
diperdengarkannya, dan ditujukan kepada target pasar yang sesuai, bila ingin berhasil dalam pemasaran ini.

Selain itu, perusahaan juga harus bisa memperhatikan nilai-nilai sosial sesuai dengan yang dipersepsikan konsumen dari iklan suara yang dimaksud, tentunya agar iklan dapat diterima dalam norma-norma sosial masyarakat, khususnya di Jakarta.

\section{Implikasi dan Kontribusi bagi PT XL Axiata:}

Untuk menjawab permasalahan yang dewasa ini dialami oleh perusahaan telekomunikasi tersebut, sebagaimana telah kami bahas pada Bab III Pendahuluan, dan berdasarkan penelitian ini, kami merekomendasikan untuk meluncurkan "layanan bertelepon gratis" melalui ponsel, dimana diperdengarkan iklan suara di dalamnya. Responden di dalam penelitian bersikap positif terhadap iklan suara selama menampilkan manfaat yang jelas, sesuai dengan norma-norma sosial yang dipersepsikan, serta tentunya ditujukan kepada target pasar yang tepat. Dengan diperdengarkannya iklan di dalam layanan ini diharapkan akan didapatkan revenue tambahan, yang bisa mengompensasi penurunan revenue yang signifikan beberapa tahun belakangan ini.

\section{KETERBATASAN PENELITIAN}

Keterbatasan waktu yang dialami membuat konsekuensi sebagai berikut:

- Nonprobability sampling yang dilakukan karena keterbatasan waktu dan biaya ini, serta convenience samples yang di dapat, sekalipun cukup sesuai memenuhi tujuan penelitian, dapat dikatakan subyektif karena mempertimbangkan faktor kepraktisan. Hal ini dapat mengakibatkan bias (penyimpangan), sehingga hasil penelitian dapat terdistorsi. Sebagai perbandingannya probability sampling secara teknis lebih akurat dan mengeliminasi bias, namun diperlukan waktu yang lebih lama dan biaya lebih tinggi (Cooper \& Schindler, 2014).

- Belum dilakukannya penelitian terhadap perusahaan iklan. Perusahaan iklan sangat menentukan keberhasilan suatu iklan bisa diterima oleh masyarkat. Iklan yang menampilkan manfaat, menghibur, dapat dipercaya, dan dipersepsikan sesuai dengan norma-norma sosial yang berlaku. 


\section{REKOMENDASI}

Rekomendasi kami dari penelitian ini adalah:

- Diadakan penelitian lanjutan terhadap perusahaan iklan sebelum diluncurkan layanan telepon gratis, agar mengetahui faktor-faktor apa yang membuat mereka tertarik untuk memasang iklan pada layanan ini.

- Sekalipun di dalam penelitian ini faktor resiko (perceived risk) dan izin konsumen (permission \& control) tidak signifikan mempengaruhi sikap negatif terhadap iklan suara, namun alangkah baiknya bila tetap dijaga kerahasiaan data nasabah dan tetap dimintakan izin dari konsumen untuk memperdengarkan iklan, agar sesuai dengan prinsip kerahasiaan dan hak pribadi konsumen (privacy principle). 
Vol.01, No. 2, 2018

\section{DAFTAR PUSTAKA}

Mansour, Ilham H.F. (2012), “Factors Affecting Konsumens' Intention to accept Mobile Advertising in Sudan”, https://www.researchgate.net/publication/260518448, (09 February 2016)

Peter J.P dan Olson JC (2010), “Konsumen Behavior \& Marketing Strategy”, McGraw-Hill International Edition (Ninth Edition), New York.

Cooper DR dan Schindler PS (2014), "Business Research Methods", McGraw-Hill International Edition (Twelveth Edition), New York.

Tsang, Melody et al (2004). "Konsumen Attitudes Toward Mobile Advertising: An Empirical Study". International Joirnal of Electronic Commerce Vol.8, No 3, Mobile Commerce Application, pp65-78. Taylor \& Francis, Ltd. http://www.jstor.org/stable/27751107

Lee, Su-Fang et al (2006). “An Empirical Examination of Customer Perceptions of Mobile Advertising".www.igi-global.com/chapter/empirical-examination-customer-perceptionsmobile/26629?camid $=4 \mathrm{v} 1$

Fishbein M and Ajzen I (1975). "Belief, Attitude, Intention and Behavior. An introduction to Theory and Research". Publishing Company, Reading MA.

Dian Siswarini (2017). "Managing digital disruption impact to business and organization". Makalah Presentasi 26 July 2017

Wikipedia Ensiklopedia Bebas (2017). “SPSS”. id.wikipedia.org (26 Januari 2017)

OnlineStatBook(2017).”Introduction to Linear

Regression".onlinestatbook.com/2/regression/intro.html 


\section{LAMPIRAN}

- Kuesioner

- Data kasar dari responden

- Analisa Data (demografi, SPSS, Regresi)

- Artikel "Sudan"

- Kuesioner "Sudan"

- Email "Sudan"

- TURNITIN Digital Receipt (plagiarism check) 
TURNITIN Digital Receipt (plagiarism check)

\section{turnitin'】)}

\section{Digital Receipt}

This receipt acknowledges that Turnitin received your paper. Below you will find the receipt information regarding your submission.

The first page of your submissions is displayed below.
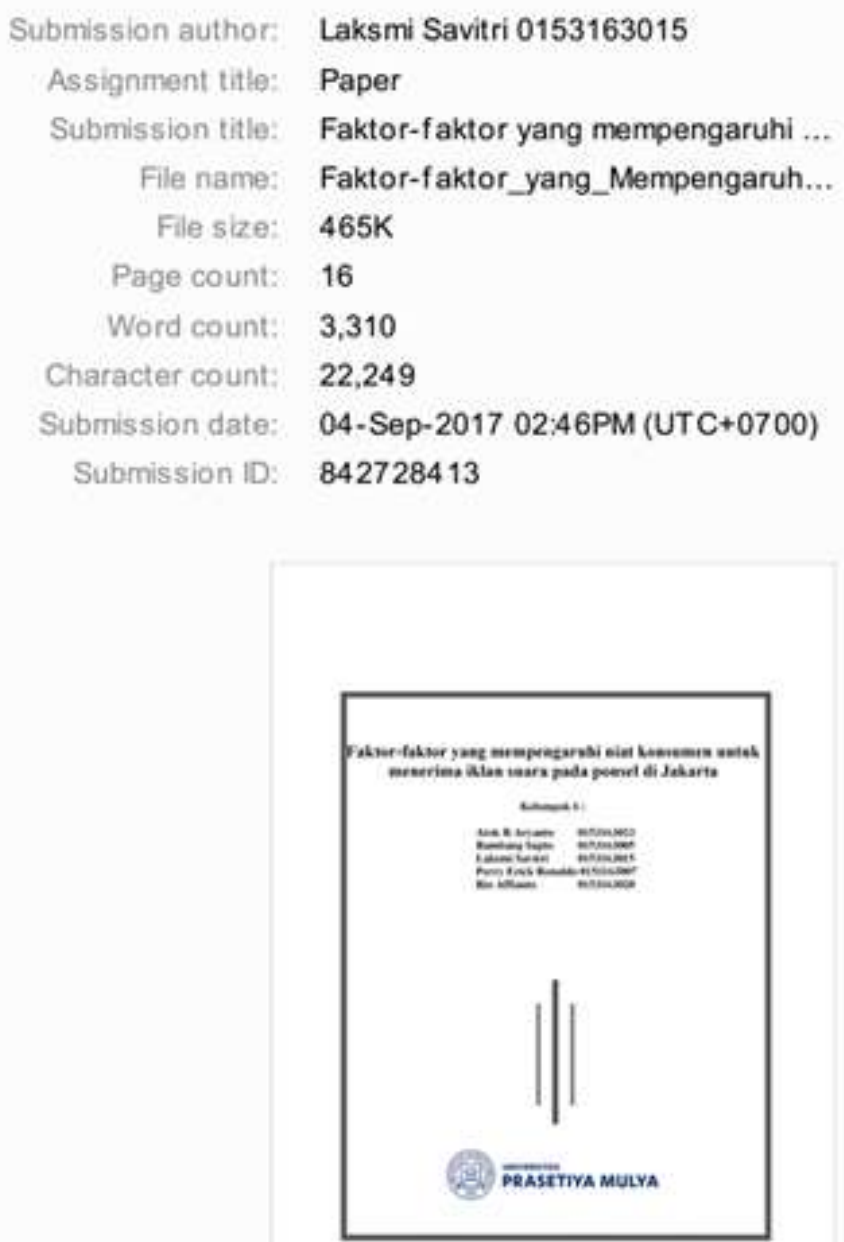
TURNITIN Digital Receipt (plagiarism check)

Faktor-faktor yang mempengaruhi niat konsumen un menerima ...

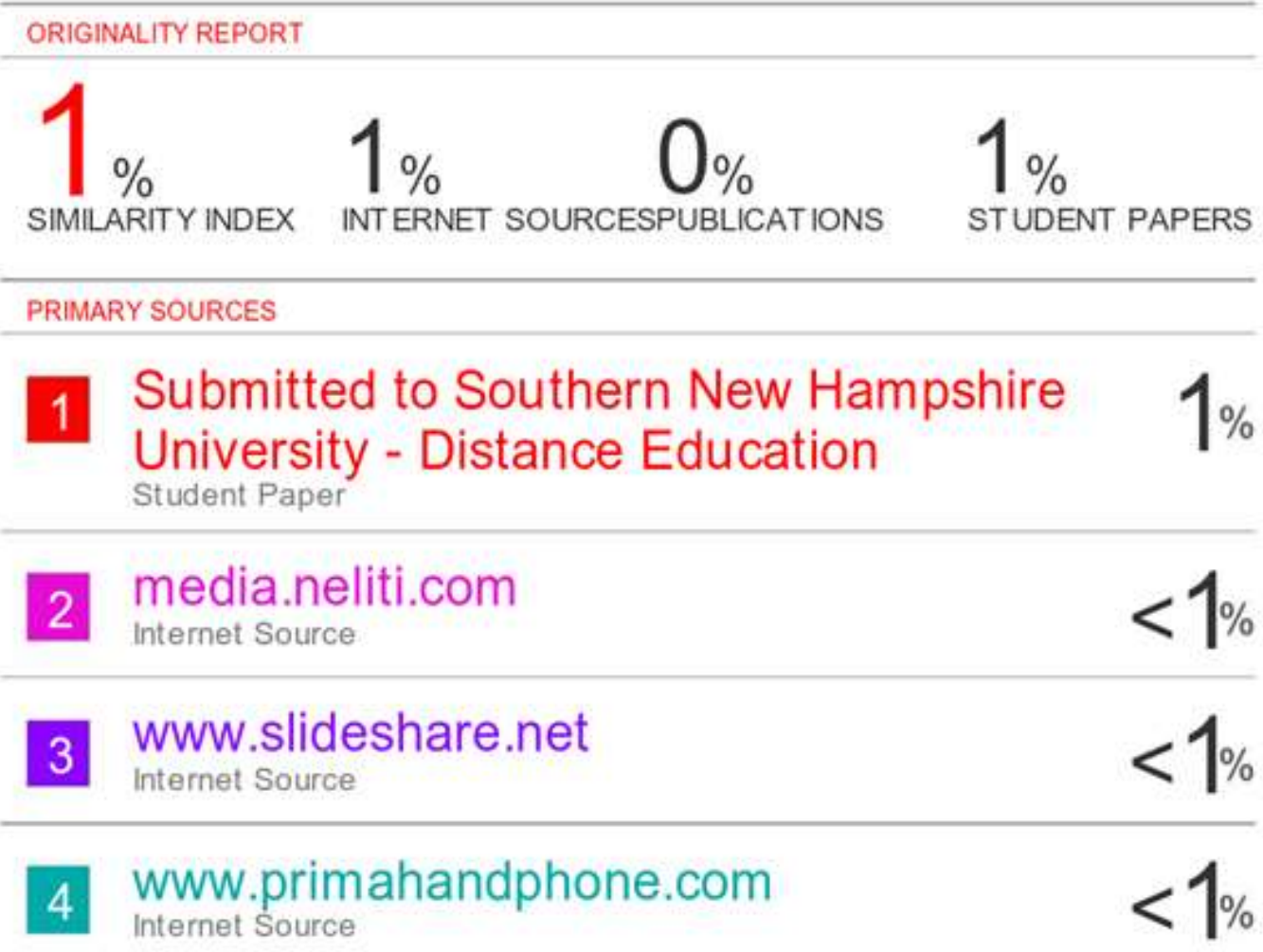

